\section{Oxford Physical Science Fellowships}

I WRITE this letter that in future candidates for Oxford Fellowships in Physical Science may be aware that outsiders are ineligible.

In June last the Warden of Merton College informed me that the election to a Physics Fellowship would not be limited to graduates of Oxford, and would altogether depend on the result of the examination held at Merton on Oct. 7. Candidates had no other information than was afforded by the notice in your columns.

Although I found that great difficulties were thrown in the way of olitsiders in their not being allowed an opportunity of examining the physical apparatus which was to be used in the examination, and with which Oxford men are well acquainted, I read for the examination, not having the slightest doubt about my eligibility after receiving the Warden's letter.

It is now nearly four months since I received the letter, and although the authorities must have been very well. aware of the grave error which had been fallen into, I was not informed that a blunder had been committed until the morning of the examination. It is now found by the Warden, on consulting the registrar of the university, that only Oxford graduates can conpete for these Fellowships.

Oxford, Oct. 8

JOHN PERRY

\section{Simple Method of Studying Wave Motion}

IT is difficult for a student to obtain a clear idea of the movement of the particles of a liquid or gas propagating a wave. To assist him models have been devised, but as a rule they are expensive and complicated. The following plan, based on the principle of the stroboscope, I have found extremely convenient. Take a piece of cardboard about $3 \mathrm{ft}$. long and $18 \mathrm{in}$. broad. Put this into the tin drum of a "zoctrope," pressing the card well against the interior of the drum, so that it stands up forming a cardboard cylinder. With a lead pencil mark where the inside fold of card comes, and you lave the right size of the cardboard to form the cylinder. Divide now the length of the cardboard into I 2 equal strips. On each strip paint dots representing the ware you want to study, taking care that cach wave is represented $i^{1}$ behind its predecessor. Lastly; cut out 12 slits, about $S$ in. by $\&$ in., between each representation of the wave; restore the card to the drum of the zoetrope, ard then turning the cylinder and observing through the slits, the wave is seen, as the cylinder revolves, to advance with its characteristic motion, while by stopping out all but one of the particles repre sented the exact character of its oscillation, whether circular, elliptical, or linear, is clearly seen

Midland Institute, Birmingham

$$
\text { C. J. WOODWARD }
$$

\section{The Glacial Period}

JUST one line in reply to Frank E. Nipher. I have read Tyndall's Lectures on Heat, and that some time before I addressed you on the subject of the Glacial Period. Plainly, it is against common sense to suppose that an increased outpour of solar energy would diminish the mean temperature of the air at the earth's surface to such an extent that glaciers at or near sea level should be found in Egypt, or even, I believe, in Central Hi: dustan, as was the case in the Glacial Period. All I can say is, that if the sun then were a hotter sun than the sun of our own asc, he must have blundered at his work.

And now may I crave space for just another line on another subject? Could not our learned societies be induced to publish their mathematical contributions separately? I was compelled to take the whole of the first part of the Royal Society's Transactions of $\mathbf{I} \delta 67$, for the sake of Clerk-Maxwell's paper on Molecules. For this I paid a guinea-willingly, in. deed; but had the paper been published alone, I should probably have had it for a much lower figure. Then therc are Professor Stokes' and Sir WV. Thomson's magnificent papers scattered up and down among the Transactions of the Royal and Cambridse Philosophical Societies; if these were gathered together and published apart, it would ba a precious boon to persons like myself who are interested in physical mathematics. And pupils of the Ecole Invariantive would, no doubt, be as much gratified by an easicr access to the numerous contributions of Professor
Cayley to the Theory of Determinants. Is it impossible, or even inconvenient, to afford such facilities to students and amateurs? Hampstcad, N.W., Oct 3

J. II. RöHRS

\section{THE OIVENS COLLEGE, MANCHESTER}

$\mathrm{T} T$ is now upwards of twenty-two years since this college was opened-for the foundation of which in Manchester, John Owens, a merchant of that city, left $100,000 l$. - in a house that belonged to Mr. Cobden, in Quay Street, which was purchased and presented to the trustces by Mr. John Faulkner, the first chairman. The number of students during the first session was 64 , which went on increasing year by year, until last session the day students numbered 327 , and the evening students 513. A few years ago it was felt that the original house had become.much too small, and that a new building ought to be crected adequate to the increased needs of the College. Accordingly, in 1866 , a circular was prepared, setting forth the disadvantages of the then institution, and propounding an extension scheme which should include the additions to the College of a school of Engineering, a Medical School, and the Natural History Mluseum, which the Council of the Natural History Society recommended should be deposited in Owens College, "if it should appear that the scheme for enlargement was likely to be successfully carried out within a reasonable period." The trustees therefore appealed for funds which would enable them to lay the foundations of an institution which would virtually be the University of South Lancashire, and of the neighbouring parts of Cheshire and Yorkshire.

In I 667 an Extension Committec was formed for raising a fund, which "it was desirable should not be less than $100,000 l$., and, if possible, $150,000 l$." to carry into effect the proposed system of extension. 24,000l. was almost immediately subscribed. The engineers of Manchester and neighbourhood subscribed 10,000 . to found and endow a chair of Engincering Science, and for the provision of an apparatus and a library. An application to the Government for a grant, though never absolutely refused, was first temporarily shelved on the familiar plea that the subject was "under consideration," and on a change of Government it was ultimately forgotten. The success of the College is therefore a monument of voluntary effort. After the present site had been purchased, the sum of I 2,cool. was subscribed towards the new Medical School. Principal Greenwood and Prof. Roscoe subsequently visited Germany, and obtained valuable information as to the schools of science in that country; and to the plans which the Professor of Chemistry cspecially brought home, the new College owes the perfect arrangements in its scientific lecture-rooms, and the handsomely fitted-up laboratories for chemical and physiological science; laboratories, we believe, which are not equalled by any in the kingdom, if, indeed, in Europe.

The foundation-stone of the buildings just completed was laid by the Duke of Devonshire in September 1870 , and the same nobleman occupied the . chair at the opening of the new building on the 7 th instant.

As is well known, the "religious difficulty" has been entirely obviated, in the case of Owens College, by the will of the founder, which requires "that the students, professors, teachers, and other officers and persons connected with the said institution, shall not be required to make any declaration as to, or submit to any test what5ocver of, their religious opinions," and that "nothing shall be introduced into the matter or mode of education or instruction, in reference to any religious or theological subject, which shall be reasonably offensive to the conscience of any student, or of his relations, guardiarıs, or friends under whose immediate care he shall be." It is no doubt partly owing to this that the Manchester 